\title{
Indoor and Outdoor Performance Study of Metallic Zinc Particles in Black Paint to Improve Solar Absorption for Solar Still Application
}

\author{
Muhammad Shakeel Ahmad ${ }^{1}$, Shwe Sin Han ${ }^{1}$, Amad Zafar ${ }^{2}$ D, Usman Ghafoor ${ }^{3}$, Nasrudin Abd Rahim ${ }^{1}$, \\ Muhammad Umair Ali ${ }^{4, *(D)}$ and You Seung Rim ${ }^{5, *}$ (D) \\ 1 Higher Institution Centre of Excellence (HICoE), UM Power Energy Dedicated Advanced \\ Centre (UMPEDAC), Level 4, Wisma R\&D, University of Malaya, JalanPantai Baharu, \\ Kuala Lumpur 59990, Malaysia; shakeelalpha@gmail.com (M.S.A.); shwesinhan2018@gmail.com (S.S.H.); \\ nasrudin@um.edu.my (N.A.R.) \\ 2 Department of Electrical Engineering, University of Lahore, Islamabad 54590, Pakistan; \\ amad.zafar@ee.uol.edu.pk \\ 3 Department of Mechanical Engineering, Institute of Space Technology, Islamabad 44000, Pakistan; \\ usmanghafoor99@gmail.com \\ 4 Department of Unmanned Vehicle Engineering, Sejong University, Seoul 05006, Korea \\ 5 Department of Intelligent Mechatronics Engineering and Convergence Engineering for Intelligent Drone, \\ Sejong University, Seoul 05006, Korea \\ * Correspondence: umair@sejong.ac.kr (M.U.A.); youseung@sejong.ac.kr (Y.S.R.)
}

check for

updates

Citation: Ahmad, M.S.; Han, S.S.; Zafar, A.; Ghafoor, U.; Rahim, N.A.; Ali, M.U.; Rim, Y.S. Indoor and Outdoor Performance Study of Metallic Zinc Particles in Black Paint to Improve Solar Absorption for Solar Still Application. Coatings 2021, 11, 536. https://doi.org/10.3390/ coatings11050536

Academic Editor: Luigi Calabrese

Received: 6 April 2021

Accepted: 28 April 2021

Published: 30 April 2021

Publisher's Note: MDPI stays neutral with regard to jurisdictional claims in published maps and institutional affiliations.

Copyright: (c) 2021 by the authors. Licensee MDPI, Basel, Switzerland. This article is an open access article distributed under the terms and conditions of the Creative Commons Attribution (CC BY) license (https:/ / creativecommons.org/licenses/by/ $4.0 /)$.

\begin{abstract}
In this study, the effects of metallic zinc ( $\mathrm{Zn}$ ) particles were studied to increase surface temperature on a solar-still absorber, which is a major component of increased production. Various concentrations of $\mathrm{Zn}$ particles were mixed in black paint and applied to the absorber plate. SEM and XRD were used to examine and confirm the surface morphology and phase identification of as-received powder. UV-Vis spectroscopy was used to examine light-absorption properties. Finally, extensive indoor testing (using an improvised solar emulator) and outdoor testing were conducted to optimize the concentration. The specimens containing $10 \mathrm{wt} \% \mathrm{Zn}$ in black paint showed the highest increase in temperature, i.e., $103.53{ }^{\circ} \mathrm{C}$ in indoor conditions at $1000 \mathrm{~W} / \mathrm{m}^{2}$ irradiation, which is $59.17 \%$ higher than a bare aluminum plate and $17.57 \%$ higher than an only black-paint-coated aluminum plate. On the other hand, specimens containing $10 \mathrm{wt} \% \mathrm{Zn}$ reached just $87.53{ }^{\circ} \mathrm{C}$, compared to $80.00{ }^{\circ} \mathrm{C}$ for an only black-paint-coated aluminum plate and $60.62{ }^{\circ} \mathrm{C}$ for bare aluminum.
\end{abstract}

Keywords: absorber; desalination; zinc; solar still; temperature; thermal conduction

\section{Introduction}

Freshwater is essential for human beings' survival, and it plays a crucial role in a sustainable environment. Therefore, the demand for potable water is increasing gradually every year due to population enlargement. Although $70 \%$ of the earth is covered with water, most of the accessible water cannot be utilized for drinking due to salinity and water contamination [1]. Various techniques, such as membrane desalination [2-4] and dialysis $[5,6]$ are used in the purification of water. One of the potential alternatives to produce fresh water and decrease the cost of distillation plants is the utilization of solar energy directly using flat collections of concentrated collectors [7]. Solar distillation is one technique to produce fresh water at a lower cost than the other possible seawater desalination processes [8,9]. Solar distillation using solar stills is the most feasible and environment-friendly way to supply fresh water in arid and remote regions [10].

Solar stills work on evaporation and condensation processes and generally consist of a water basin and a transparent cover that allows sunlight penetration and stimulates the evaporation process. The evaporated water condenses on the backside of the top cover and 
is collected accordingly. However, solar stills are characterized by their low productivity compared to other desalination techniques. This is mainly because of the temperatures available within the box due to less solar absorption and obvious intermittence [11].

One of the main components contributing a lot to solar still production efficiency is the base plate, which acts as the solar radiation absorber and provides the required energy to water. Generally, aluminum or copper plates coated with black paints have been employed for maximum radiation absorption. In a recent study, $\mathrm{TiO}_{2}$ nanoparticles were mixed with black paint and coated on the absorbed plate to increase radiation absorption. A $1.5^{\circ} \mathrm{C}$ increase in water temperature was reported for $\mathrm{TiO}_{2}$-modified black paint compared to bare black paint. This increase in temperature led to a $6.1 \%$ increase in solar-still distillate yield [12]. In another study, $\mathrm{ZnO}$ nanoparticulates were investigated as a reinforcement for the absorber plate. An absorber temperature of $70^{\circ} \mathrm{C}$ was reported when coated with nano tubular-shaped $\mathrm{ZnO}$ particles/black paint, compared to the $60-65{ }^{\circ} \mathrm{C}$ temperature of the reference sample [13]. Various other nanomaterials such as carbon nanotubes and graphene have been employed to achieve maximum temperature [14]. Graphene has proven to be a promising material for solar thermal absorption, but its high cost is still an issue. Recently, a cost-effective and environment-friendly method of reducing grapheme oxide to grapheme has been proposed, which may prove to be helpful in the cost-reduction of graphene production [15]. Graphene has also been used along with carbon pellets for improved distillate yield and reduced capital investment [16]. The analysis suggested results $15.5 \%$ lower than conventional solar stills. In still another study, a marked improvement in distillate yield was reported using nano ferric oxide particles [17].

Similarly, $\mathrm{CuO}$ with various weight concentrations, ranging from 10 to $40 \%$, has also been considered a nanomaterial and was added to the black paint of solar-still walls to enhance solar-still performance. Results suggested that utilizing $\mathrm{CuO}$ nanoparticles boosted the distillate by 16 and $25 \%$ compared to the conventional solar still at weight fraction concentrations of 10 and $40 \%$, respectively [18]. Another experimental study investigated the fumed $\mathrm{SiO}_{2}$ nanoparticle in black paint at varied concentrations from 10 to $40 \%$ coated on the absorber plate of a stepped solar still for augmenting the freshwater yield. The average temperature of the absorber plate increased by $12.3 \%$ by adding the optimized concentration of nanoparticles, i.e., $20 \mathrm{wt} \%$, to black paint. Results also concluded that the total yield from the solar still improved by $27.2,34.2,18.3$, and $18.4 \%$ for $10,20,30$, and $40 \%$ concentration, respectively, compared to ordinary black paint [19]. In another study, an increase of $6.8 \%$ was reported for using white paint on the interior of a solar still compared to black paint [20]. In another recent study, $\mathrm{CuO}$ nanoparticles $(0.04 \mathrm{vol} \%)$ were used in black paint to improve the solar dryer's surface temperature. The maximum reported temperature was approximately $96^{\circ} \mathrm{C}$, tested in Coimbatore (latitude 110,183 N; longitude $769,725 \mathrm{E}$ ) at noon [21].

Furthermore, some studies suggested mixing various nanoparticles, e.g., $\mathrm{CuO}, \mathrm{Al}_{2} \mathrm{O}_{2}$, $\mathrm{TiO}_{2}$, etc., directly with water for simplicity of operation [22-24]. In one study, experimental comparisons were investigated between the solid nanoparticles of $\mathrm{CuO}$ and $\mathrm{Al}_{2} \mathrm{O}_{3}$ nanofluid and concluded that the nanoparticles enhanced freshwater production by around 125.0 and $133.64 \%$, respectively [25]. But this approach (nanofluids) could contaminate the water due to its direct contact with water [13]. Other improved distillate yield approaches include wick materials, such as cotton, wool, nylon, wood pulp paper, styrene sponge, coral fleece, etc., and the shape-modification of the absorber plate to improve contact surface area have been employed with promising results.

Various studies have examined the topical issue of increasing the yield of freshwater from the solar still using a well-known approach, i.e., an increase in the emissivity of a container with water irradiated by the sun. Increased water temperature in the tank leads to increased water evaporation and, therefore, increases the yield of freshwater. But to date, no study has been conducted in both controlled (indoor) and outdoor environments to fully evaluate the potential. In this study, spherical particles of metallic zinc have been studied to improve the absorption property of an absorber plate for solar-still applications. 
Various concentrations of $\mathrm{Zn}$ were mixed with black paint and applied to the aluminum plate. Indoor and outdoor testing was conducted using an improvised apparatus for concentration optimization.

\section{Experimental Investigation}

\subsection{Samples Preparation}

The test samples were prepared using a simple chemical mixing method. Black paint was used as a base matrix to paint onto an aluminum plate, and $\mathrm{Zn}$ nanoparticles in the various fractions $0.5,1,3,5,7,10,15$, and $20 \mathrm{wt} \%$ were mixed in black paint. In brief, the nanoparticles were suspended in isopropyl alcohol $(5 \mathrm{~mL})$, sonicated for $1 \mathrm{~h}$ and stirred for $5 \mathrm{~h}$ into a proper suspension. The suspension was mixed with black paint using a mechanical mixer, and the now-formed formulation was applied to the aluminum plate using a hand brush. The samples were dried at room temperature for $24 \mathrm{~h}$. The same procedure was repeated for each concentration. A clean black-painted aluminum plate and a bare aluminum plate of the same dimensions were also prepared for comparative purposes. Figure 1 shows the prepared samples for testing.

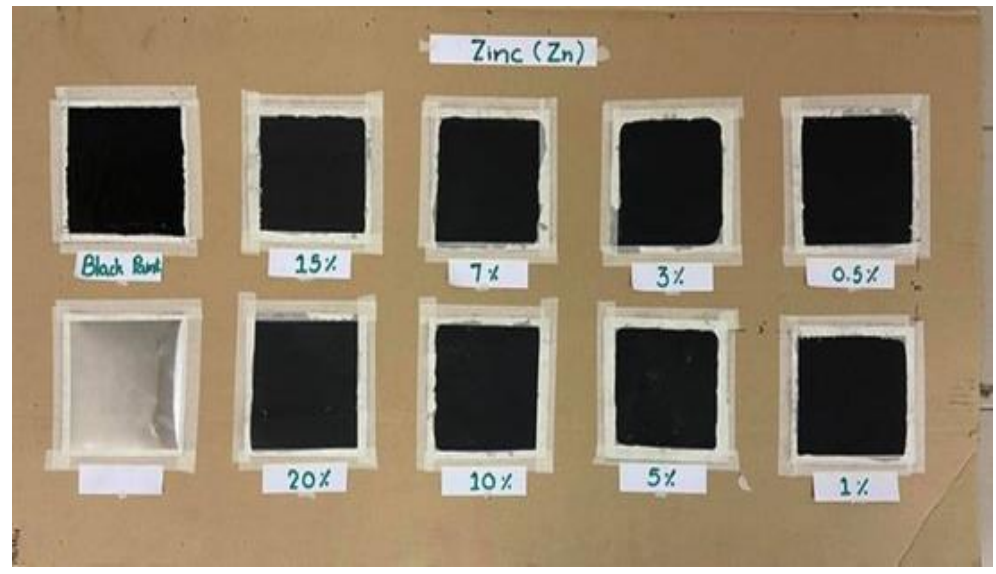

Figure 1. Arrangement of samples.

\subsection{Indoor Setup and Experimental Procedure}

The indoor investigation was carried out at the solar thermal laboratory, UMPEDAC, the University of Malaya, using a solar emulator. The room temperature was set to $25^{\circ} \mathrm{C}$ using a central air conditioning system under virtually still air. There were many components and instruments used in this experiment to fulfill the required indoor conditions. For providing the required irradiation, a solar emulator comprising 120 halogen bulbs (brand: OSRAM) with power, voltage, and current capacity of $90 \mathrm{~W}, 12 \mathrm{~V}$, and $7.5 \mathrm{~A}$, respectively, was used. The solar emulator was controlled by three variable control AC power-supply transformers that could simulate solar radiation from $100 \mathrm{~W} / \mathrm{m}^{2}$ to $1200 \mathrm{~W} / \mathrm{m}^{2}$ [26]. Furthermore, a few other standard measuring instruments were used to record data. Some essential instrumentation and sensors used were a pyranometer (brand: LI-COR, LI200R), data logger brand: Data Taker (DT80), and thermocouples (K-type). The measuring and accuracy range of all the instruments and sensors is given in Table 1. The temperature of the room was set to $25^{\circ} \mathrm{C}$ using a central air conditioning system.

Table 1. Measurement ranges and accuracy of the instruments and sensors.

\begin{tabular}{ccc}
\hline Instrument & Measuring Range & Accuracy \\
\hline Pyranometer (model: LI-COR, LI200R) & 0 to $2000 \mathrm{~W} / \mathrm{m}^{2}$ & $\pm 2 \%$ \\
Data Logger (model: Data Taker DT80) & $-45{ }^{\circ} \mathrm{C}$ to $70{ }^{\circ} \mathrm{C}$ (operational range) & $\pm 2 \%$ \\
Thermocouple (K-type) & -200 to $1260^{\circ} \mathrm{C}$ & $\pm 5 \%$ \\
\hline
\end{tabular}


For the indoor experiment procedure, the samples of size $6^{\prime \prime} \times 6^{\prime \prime}$ were placed on a cardboard in the solar emulator. The samples with different concentrations of $\mathrm{Zn}$ particlecoated plates were placed in two rows with displacement 3 inches apart on the cardboard. A bare aluminum plate and an only black-paint-coated aluminum plate were also placed on the same board for comparative purposes. The K-type thermocouple was placed on each plate by placing fiberglass wool (insulating material) in between the thermocouple bed and adhesive tape to avoid the thermocouple's direct heating. The experiments were conducted at various irradiation levels in indoor working conditions. Five samples for each concentration were tested, and the average maximum temperature is presented. The standard deviation for all the readings ranged between $\pm 2 \%$ and $\pm 3 \%$. It was observed that it took about $30 \mathrm{~min}$ in each irradiation level of an experiment to reach stable conditions. Then the solar emulator was switched off for about $15 \mathrm{~min}$ to record all plates' decreasing temperature. The arrangement of the indoor experiment is systematically depicted in Figure 2.

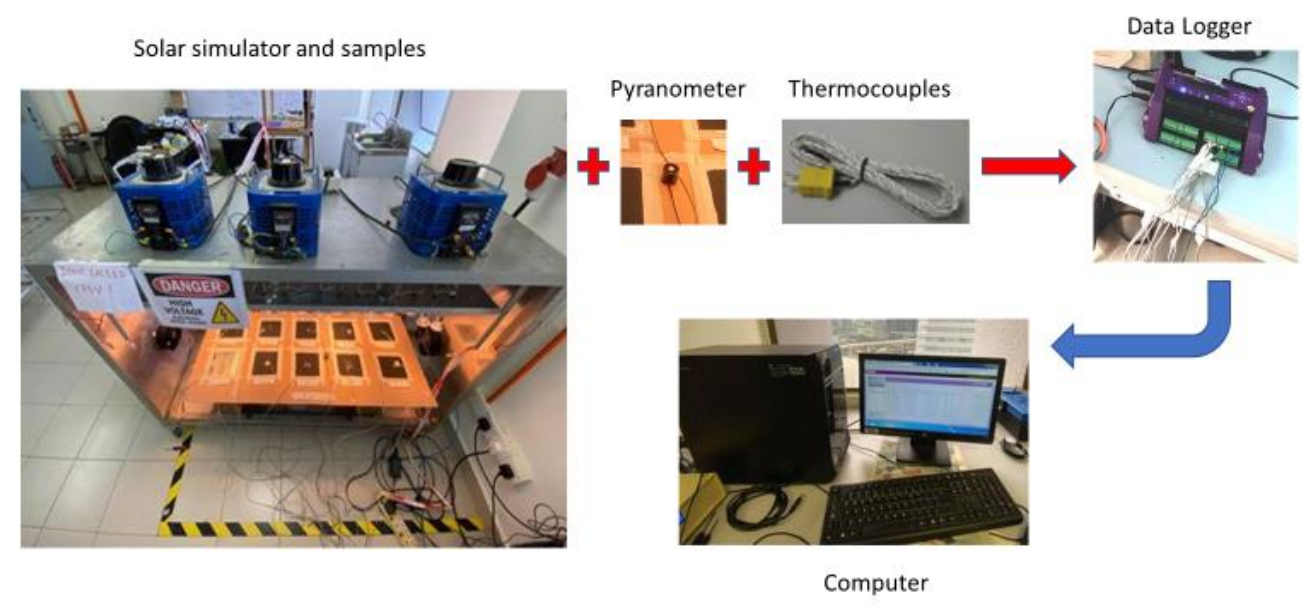

Figure 2. Indoor experimental setup.

\subsection{Outdoor Setup and Experimental Procedure}

The outdoor experimental setup has been installed in the solar garden of the Higher Institution Centre of Excellence, UM Power Energy Dedicated Advanced Centre (UMPEDAC), Kuala Lumpur, Malaysia. Experiments were carried out from 8:00 a.m. to 5:00 p.m. The same standard devices and instruments were used to record the data. The measuring and accuracy ranges of all the instruments and sensors are given in Table 1. Sensors were placed in the system at the necessary locations for recording the data. Other meteorological data, such as wind speed, humidity, etc., were measured using the weather station installed at the solar garden.

The same arrangement of samples, i.e., zinc-coated nanoparticles, the plate coated with black paint, and the aluminum plate, was attached to a wooden sheet with a thickness of 1" and mounted at an optimum inclined angle of 15 degrees. It is worth mentioning here that only the best performing and uniformly coated samples for each concentration (i.e., $0.5 \mathrm{wt} \%$, $1 \mathrm{wt} \%, 3 \mathrm{wt} \%, 5 \mathrm{wt} \%, 7 \mathrm{wt} \%, 10 \mathrm{wt} \%, 15 \mathrm{wt} \%$, and $20 \mathrm{wt} \%)$ under indoor conditions were tested in outdoor conditions and compared with an only black-paint-coated aluminum plate and a bare aluminum plate. The layout of the outdoor experiment, including the position and connectivity of all instruments and components, are systematically represented in Figure 3. The optimum angle was calculated using Cooper's Equation (1) to intercept the maximum radiation throughout the day.

$$
\delta=23.45 \sin \left[0.9863\left(284+n_{1}\right)\right]
$$

where $\delta$ is the inclination angle, and $n_{1}$ is the day of the year. 


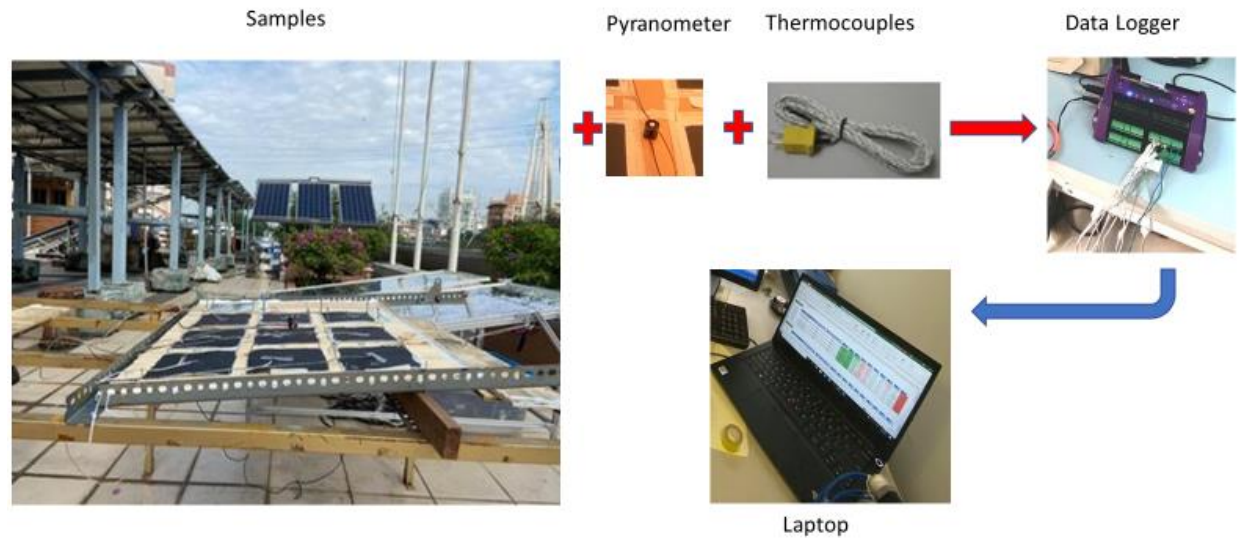

Figure 3. Outdoor experimental setup.

\section{Results and Discussion}

Figure 4 shows the scanning electron micrographs (SEM) (model: Tescan Mira3, Tescon, Kohoutovice, Czech Republic) along with X-ray diffraction (XRD) (Bruker D8 discover, Bruker, Germany) and UV-visible spectroscopy (model: UV-3600i Plus UV-VisNIR Spectrophotometer, the range set to 200-1100 nm, Shimadzu, Japan) to understand the surface-morphology, composition, and light-absorption characteristics of as-received Zn particles. Powder samples were used for all three characterizations. For SEM, the powder was dispersed in ethanol and sonicated for $30 \mathrm{~min}$. After that, the suspension was drop-casted on an aluminum stub covered by carbon double-tap. For Uv-Vis-Nir spectroscopy, the sample suspension used neat ethanol as a reference in reference cuvettes. To measure the UV-Vis spectra of black paint, $0.30 \mathrm{~mL}$ of black paint was mixed with $5 \mathrm{ml}$ of ethanol, and the diluted solution was tested. It is evident from Figure 4a that the particles are spherical with a rough surface texture. The size of the particles ranged from micron to submicron size, but the majority of particles are in the micron-sized range. Figure $4 \mathrm{~b}$ shows the XRD pattern of the as-received Zn particles with miller indices. The diffraction pattern was matched with JCPDS number 00-004-0784 for confirmation. Little to no zinc oxide peaks have been detected. Figure 4c shows the UV-Vis spectra of as-received particles and black paint. A sharp absorption at around $350 \mathrm{~nm}$ in the UV region was identified, followed by a reduction in absorption. A second sharp absorption was identified in the near-infrared region with onset starting at the visible region of the solar spectrum. On the other hands, black paint shows light absorption only in the visible region. This high absorption in the UV $(230-350 \mathrm{~nm})$ and near-infrared $(990-1030 \mathrm{~nm})$ regions indicates high sunlight-absorption properties that helped improve the surface temperature of the absorber plate.

The notable outcome of the performance of the absorber plates is properly analyzed from the evidence and presented in detail with results and insightful discussion. In the following sections, the indoor and outdoor experiment results are presented, demonstrating complete graphical information about the beneficial effects of using various $\mathrm{Zn}$ concentrations with black paint.

\subsection{Kuala Lumpur Weather Profile}

The variation of maximum and minimum ambient temperatures, relative humidity, wind speed and direction, precipitation, and cloud cover across the year from December 2019 to 2020 is shown in Figure 5. It can be seen that the profile is almost consistent, with an average temperature of $25^{\circ} \mathrm{C}$ throughout the year. However, a maximum and minimum temperature of $34^{\circ} \mathrm{C}$ and $23^{\circ} \mathrm{C}$ was also seen in March. Kuala Lumpur is located in the equatorial region with two monsoon seasons in a year, namely the northeast and southwest. 

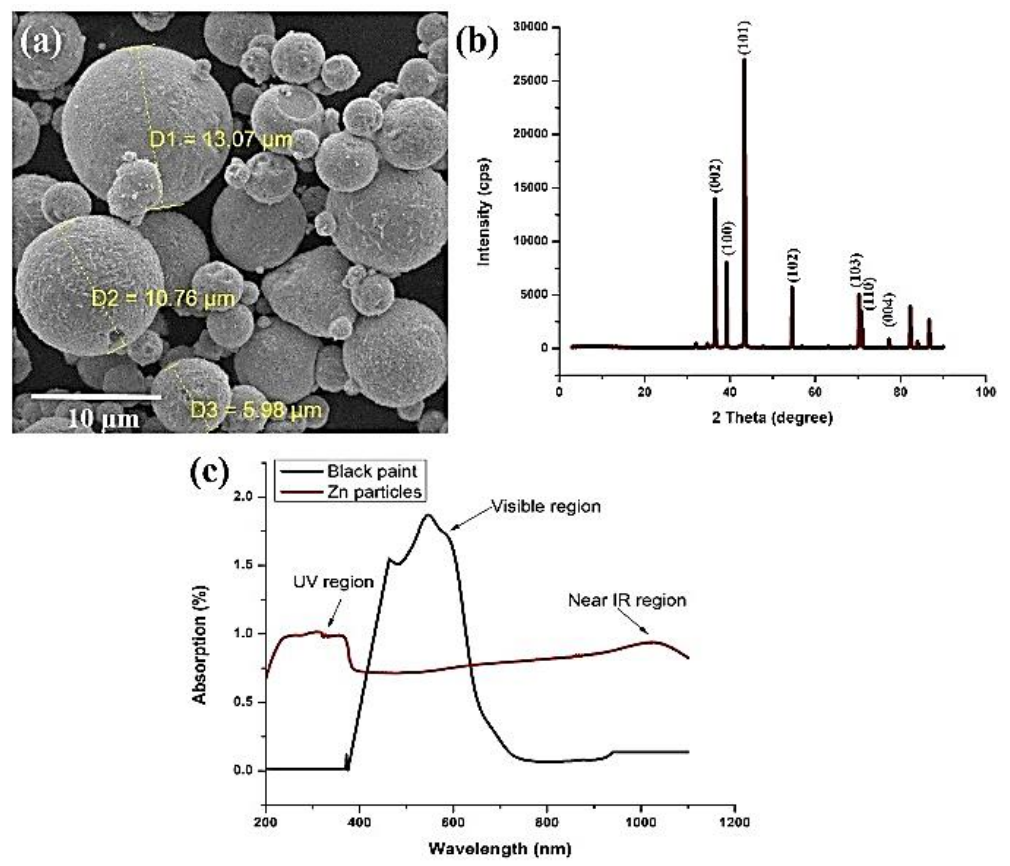

Figure 4. (a) SEM micrograph, (b) XRD pattern, and (c) UV-Vis spectra of as-received Zn powder and black paint (matrix).

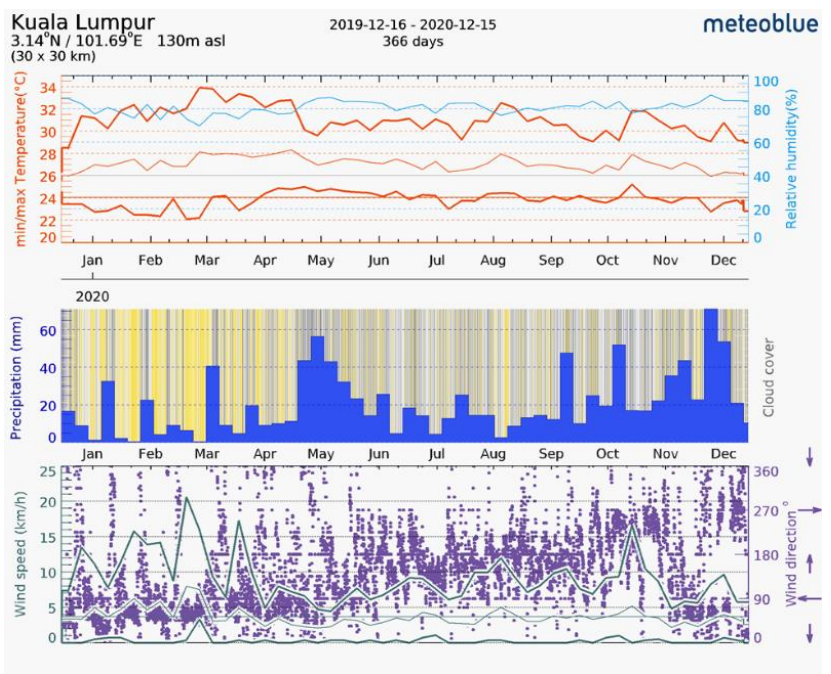

Figure 5. Historical weather data in Kuala Lumpur from December 2019 to 2020 [27].

\subsection{Indoor Analysis}

The indoor experiment was conducted by varying irradiation from 100 to $1000 \mathrm{~W} / \mathrm{m}^{2}$. However, for analysis purposes, the effect of temperature on the absorber plates under the increment of $200 \mathrm{~W} / \mathrm{m}^{2}$ and the rate of drop in temperature is shown in Figure 6 (a-di). The left-hand side of Figure 6 illustrates the effect of 200, 600, 800, and $1000 \mathrm{~W} / \mathrm{m}^{2}$ on the absorber plate temperature, and the right-hand side illustrates the rate of temperature drop (cooling curve) in $15 \mathrm{~min}$ intervals. The initial increase in the temperature is directly related to thermal properties, i.e., absorption and uniform distribution of the heat in the material. After that, the rise in temperature slows down and becomes almost linear. This linearity shows that the maximum temperature has been achieved. Furthermore, thermal convection is the only mode of heat transfer to the surrounding environment, which caused linearity (balance) in the temperature at the peak point. An increase in temperature with an 
increase in irradiation was observed, as shown in Figure $6 \mathrm{a}-\mathrm{d}$. Furthermore, increments in the concentration of particles in black paint also increased the surface temperature. This is due to the ability of $Z n$ particles to absorb UV irradiation. The optimum concentration of $\mathrm{Zn}$ has been observed to be $10 \mathrm{wt} \%$ in black paint. The maximum temperatures 55.26 , $82.12,94.67$, and $103.56{ }^{\circ} \mathrm{C}$ were observed for specimens containing $10 \mathrm{wt} \% \mathrm{Zn}$ in black paint at $200,600,800$, and $1000 \mathrm{~W} / \mathrm{m}^{2}$ respectively. Further increments in concentration did not increase the surface temperature, which can be explained based on cooling curves. Figure 6ai-di shows the cooling curves of the specimens. It can be observed that, with an increase in the concentration of $\mathrm{Zn}$ particles in black paint, the cooling rate increased. This increase in cooling rate is due to the high thermal conductivity of Zn particles, which causes excessive convective losses when the concentration exceeded the optimum value. All the cooling curves of specimens at each irradiation level follow the same trend.

(a)

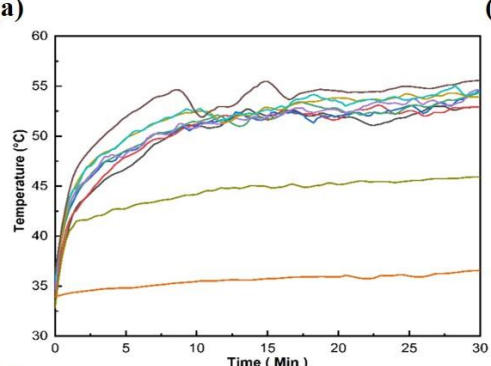

(b)

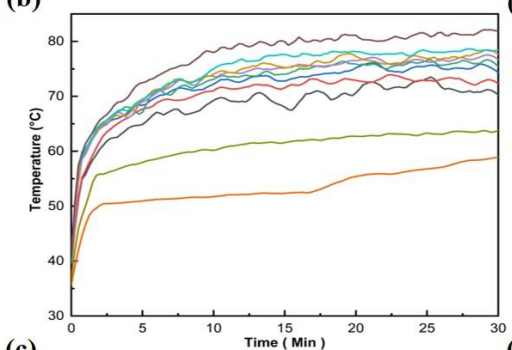

(c)

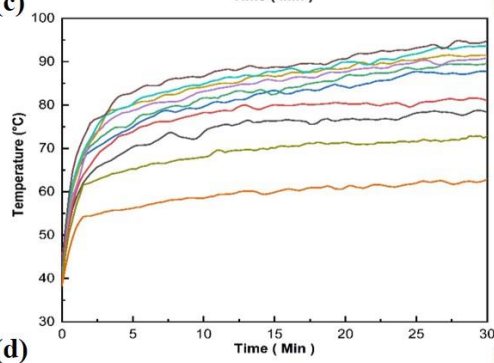

(d)

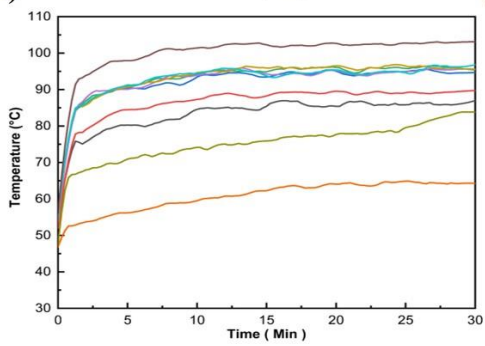

(ai)

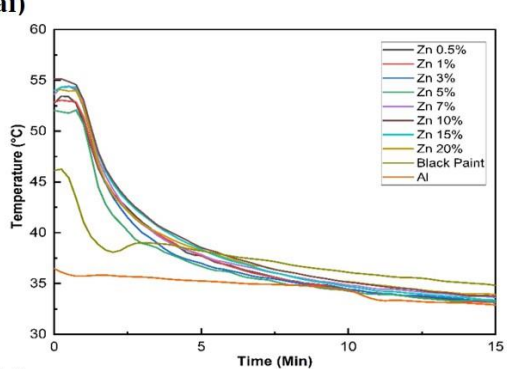

(bi)
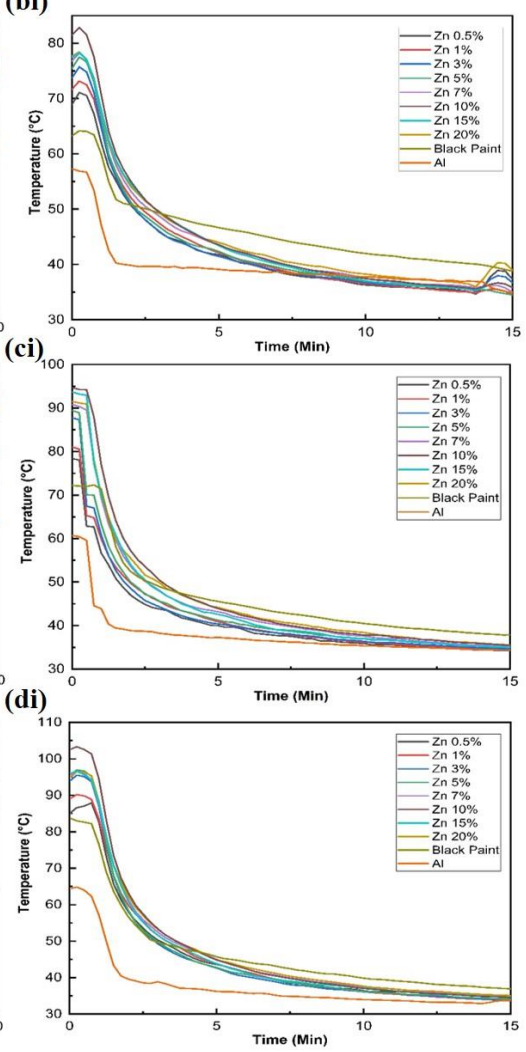

Figure 6. Effect on absorber temperature at irradiation exposure of (a) $200 \mathrm{~W} / \mathrm{m}^{2},(\mathbf{b}) 600 \mathrm{~W} / \mathrm{m}^{2}$, (c) $800 \mathrm{~W} / \mathrm{m}^{2}$, and (d) $1000 \mathrm{~W} / \mathrm{m}^{2}$ and temperature-drop profile (ai, bi, ci, and di).

Table 2 summarizes the temperatures recorded for each concentration at $1000 \mathrm{~W} / \mathrm{m}^{2}$ irradiation level. The maximum temperature values of all the samples, along with mean value and standard deviation, are presented in Appendix A. The bare aluminum plate's surface temperature was recorded to be $65.04{ }^{\circ} \mathrm{C}$, whereas the aluminum plate coated 
with only black paint shows an $83.80{ }^{\circ} \mathrm{C}$ temperature, which is around $28.25 \%$ higher. This is due to the high irradiation-absorption property of black color and low thermal conductivity of paint. The introduction of $0.5 \mathrm{wt} \% \mathrm{Zn}$ particles in black paint increased the temperature to $88.06{ }^{\circ} \mathrm{C}$, which is a $5.06 \%$ increase compared to the only black paint and $35.37 \%$ higher compared to the bare aluminum plate. At $1 \mathrm{wt} \%$ concentration, the recorded temperature reached $90.14{ }^{\circ} \mathrm{C}$, which is $7.56 \%$ higher than only black paint and $38.57 \%$ higher compared to bare aluminum. At $3 \mathrm{wt} \%$ concentration, the recorded temperature reached $96.01^{\circ} \mathrm{C}$, which is $14.57 \%$ higher than only black paint and $47.62 \%$ higher compared to bare aluminum. Further, the temperature increments with concentrations up to $10 \mathrm{wt} \%$ reached a maximum temperature of $103.56^{\circ} \mathrm{C}$, which is $23.58 \%$ higher than only black paint and $59.22 \%$ higher compared to bare aluminum.

Table 2. Summary of indoor analysis for the maximum temperature at different radiations.

\begin{tabular}{|c|c|c|c|}
\hline Sr. No & Matrix & $\begin{array}{l}\text { Zn Concentration } \\
\text { (wt. \%) }\end{array}$ & $\begin{array}{c}\text { Maximum Temperature }\left({ }^{\circ} \mathrm{C}\right) \\
\text { at } 200 \mathrm{~W} / \mathrm{m}^{2}\end{array}$ \\
\hline 1 & Black paint & $0.5 \%$ & $53.40 \pm 2 \%$ \\
\hline 2 & Black paint & $1 \%$ & $53.26 \pm 2 \%$ \\
\hline 3 & Black paint & $3 \%$ & $54.80 \pm 2 \%$ \\
\hline 4 & Black paint & $5 \%$ & $54.55 \pm 3 \%$ \\
\hline 5 & Black paint & $7 \%$ & $54.81 \pm 2 \%$ \\
\hline 6 & Black paint & $10 \%$ & $55.94 \pm 2 \%$ \\
\hline 7 & Black paint & $15 \%$ & $54.99 \pm 3 \%$ \\
\hline 8 & Black paint & $20 \%$ & $54.83 \pm 3 \%$ \\
\hline 9 & Black paint & $0 \%$ & $45.95 \pm 2 \%$ \\
\hline \multirow[t]{2}{*}{10} & Aluminum & - & $34.29 \pm 3 \%$ \\
\hline & & & $\begin{array}{c}\text { Maximum Temperature }\left({ }^{\circ} \mathrm{C}\right) \\
\text { at } 600 \mathrm{~W} / \mathrm{m}^{2}\end{array}$ \\
\hline 11 & Black paint & $0.5 \%$ & $73.68 \pm 2 \%$ \\
\hline 12 & Black paint & $1 \%$ & $74.29 \pm 2 \%$ \\
\hline 13 & Black paint & $3 \%$ & $76.57 \pm 3 \%$ \\
\hline 14 & Black paint & $5 \%$ & $77.11 \pm 2 \%$ \\
\hline 15 & Black paint & $7 \%$ & $77.84 \pm 3 \%$ \\
\hline 16 & Black paint & $10 \%$ & $82.29 \pm 2 \%$ \\
\hline 17 & Black paint & $15 \%$ & $78.72 \pm 2 \%$ \\
\hline 18 & Black paint & $20 \%$ & $78.51 \pm 2 \%$ \\
\hline 19 & Black paint & $0 \%$ & $63.82 \pm 3 \%$ \\
\hline \multirow[t]{2}{*}{20} & Aluminum & - & $41.93 \pm 2 \%$ \\
\hline & & & $\begin{array}{c}\text { Maximum Temperature }\left({ }^{\circ} \mathrm{C}\right) \\
\text { at } 800 \mathrm{~W} / \mathrm{m}^{2}\end{array}$ \\
\hline 21 & Black paint & $0.5 \%$ & $78.96 \pm 2 \%$ \\
\hline 22 & Black paint & $1 \%$ & $81.90 \pm 3 \%$ \\
\hline 23 & Black paint & $3 \%$ & $87.91 \pm 2 \%$ \\
\hline 24 & Black paint & $5 \%$ & $89.68 \pm 2 \%$ \\
\hline 25 & Black paint & $7 \%$ & $90.85 \pm 2 \%$ \\
\hline 26 & Black paint & $10 \%$ & $94.94 \pm 2 \%$ \\
\hline 27 & Black paint & $15 \%$ & $93.72 \pm 3 \%$ \\
\hline 28 & Black paint & $20 \%$ & $91.65 \pm 3 \%$ \\
\hline 29 & Black paint & $0 \%$ & $72.86 \pm 2 \%$ \\
\hline \multirow[t]{2}{*}{30} & Aluminum & - & $44.95 \pm 2 \%$ \\
\hline & & & $\begin{array}{c}\text { Maximum Temperature }\left({ }^{\circ} \mathrm{C}\right) \\
\text { at } 1000 \mathrm{~W} / \mathrm{m}^{2}\end{array}$ \\
\hline 31 & Black paint & $0.5 \%$ & $88.06 \pm 3 \%$ \\
\hline 32 & Black paint & $1 \%$ & $90.14 \pm 2 \%$ \\
\hline 33 & Black paint & $3 \%$ & $96.01 \pm 3 \%$ \\
\hline 34 & Black paint & $5 \%$ & $97.02 \pm 2 \%$ \\
\hline 35 & Black paint & $7 \%$ & $98.32 \pm 2 \%$ \\
\hline 36 & Black paint & $10 \%$ & $103.56 \pm 2 \%$ \\
\hline 37 & Black paint & $15 \%$ & $97.09 \pm 3 \%$ \\
\hline 38 & Black paint & $20 \%$ & $97.65 \pm 2 \%$ \\
\hline 39 & Black paint & $0 \%$ & $83.80 \pm 2 \%$ \\
\hline 40 & Aluminum & - & $65.04 \pm 2 \%$ \\
\hline
\end{tabular}




\subsection{Outdoor Analysis}

The weather of Kuala Lumpur is an equatorial climate featuring hot and humid weather throughout the whole year. The southwest monsoon takes place from April to September, and the northeast monsoon occurs from October to March. The southwest monsoon highlights a drier climate with less precipitation contrasted with the northeast monsoon, which brings more rainfall [28]. In this research study, the outdoor experiments were conducted from 8:00 a.m. to 5:00 p.m. for about five days in the last week of September, and the data for the best sunny day is presented in Figure 7. It was noted that tropical thunderstorms and rainfall usually occurred in the afternoon, although the weather conditions were generally good in the morning during the experiments.

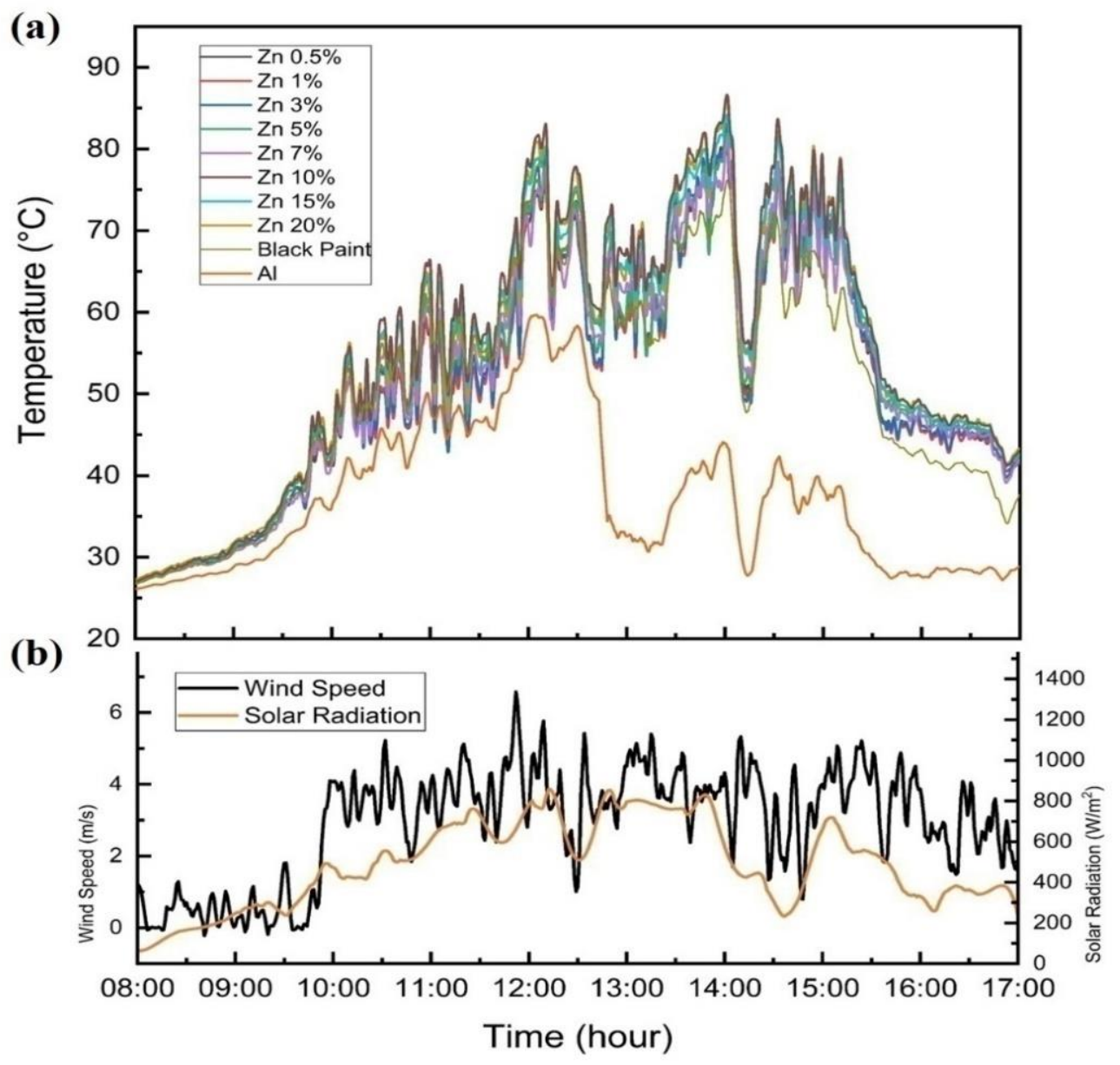

Figure 7. (a) Outdoor Experiment Data of absorber plates associated with (b) weather condition at 27 th Sept 2020.

Figure 7a,b shows the outdoor temperature of specimens under investigation with time duration, solar irradiation levels and wind speed (being recorded by a weather station) on a particular day. It was observed that the outdoor data follows the same trend as indoor experimental data. The maximum recorded temperature for each specimen is summarized in Table 3. The highest temperature, $87.50^{\circ} \mathrm{C}$, was observed for a specimen containing $10 \mathrm{wt} \% \mathrm{Zn}$ particles, which is $9.37 \%$ higher than only black paint and $44.38 \%$ higher than a bare aluminum plate. This is due to optimum light absorption and thermal conductivity. Further increments did not improve the surface temperature mainly due to convective heat losses caused by higher thermal conductivity, which was observed during indoor cooling. 
Table 3. Summary of outdoor analysis for maximum temperature and average temperature.

\begin{tabular}{ccccc}
\hline Sr. No & Matrix & $\begin{array}{c}\text { Zn Concentration } \\
(\mathbf{w t .} \%)\end{array}$ & $\begin{array}{c}\text { Average } \\
\text { Temperature }\left({ }^{\circ} \mathbf{C}\right)\end{array}$ & $\begin{array}{c}\text { Maximum } \\
\text { Temperature }\left({ }^{\circ} \mathbf{C}\right)\end{array}$ \\
\hline 1 & Black paint & $0.5 \%$ & 51.7 & 81.8 \\
2 & Black paint & $1 \%$ & 51.8 & 83.2 \\
3 & Black paint & $3 \%$ & 52.2 & 82.6 \\
4 & Black paint & $5 \%$ & 53.0 & 82.7 \\
5 & Black paint & $7 \%$ & 52.5 & 84.2 \\
6 & Black paint & $10 \%$ & 55.9 & 87.5 \\
7 & Black paint & $15 \%$ & 54.9 & 86.4 \\
8 & Black paint & $20 \%$ & 55.4 & 84.5 \\
9 & Black paint & $0 \%$ & 51.2 & 80.0 \\
10 & Aluminum & - & 37.1 & 60.6 \\
\hline
\end{tabular}

After carefully analyzing indoor and outdoor performance, a significant difference was observed. For instance, under an indoor environment, the performance increase for $10 \mathrm{wt} \%$ specimens was 23.85 and $59.22 \%$ compared to the black paint and bare aluminum plate. Whereas in outdoor conditions, though the trend was the same, the noted increase in the performance was 9.37 and $44.38 \%$ for the black paint and bare aluminum plate, respectively. This behavior is due to high convective losses due to wind and solar intermittence under uncontrolled outdoor conditions. The difference between indoor controlled and outdoor uncontrolled conditions for specimens containing optimum concentration and black-paint-coated samples is much less than the difference between the highest performing specimens and the bare aluminum plate under indoor and outdoor conditions. This is because of the much lower thermal conductivity of black paint compared to a bare aluminum plate. It is worth mentioning that, like all incandescent light bulbs, a halogen lamp produces a continuous spectrum of light, from near-ultraviolet to deep into the infrared. This makes halogen lamps the only option for consumer light sources with a black-body radiation spectrum like the sun. With this information, the spectrum in indoor and outdoor conditions will remain the same with minimal deviation.

\section{Conclusions}

Solar-still technology is improving at an incredible pace to avoid the future scarcity of fresh drinking water. In this study, $\mathrm{Zn}$ particles were investigated to increase the sunlight absorption of a solar-still absorber plate. Various concentrations of metallic zinc particles were mixed with black paint and applied to the absorber plate. SEM and XRD were employed to examine surface morphology and composition, respectively. UV-Vis spectroscopy was conducted to study the optical absorption properties of $\mathrm{Zn}$. Indoor and outdoor tests were conducted using an improvised apparatus. With the introduction of $\mathrm{Zn}$ particles in black paint, a temperature rise was observed, which can be associated with the ability of zinc to absorb sunlight in UV and the near-infrared range of the solar spectrum. The highest temperature, $103.53{ }^{\circ} \mathrm{C}$, was recorded for samples containing $10 \mathrm{wt} \% \mathrm{Zn}$ in indoor conditions at $1000 \mathrm{~W} / \mathrm{m}^{2}$ irradiation levels, whereas the same samples, with $10 \mathrm{wt} \%$ $\mathrm{Zn}$, performed best in outdoor conditions, achieving a maximum of $87.53{ }^{\circ} \mathrm{C}$. Further increments in concentration did not effectively improve absorption characteristics.

Author Contributions: Conceptualization, M.S.A. and U.G.; Formal analysis, S.S.H. and N.A.R.; Funding acquisition, Y.S.R.; Investigation, S.S.H., A.Z., and M.U.A.; Methodology, M.S.A.; Project administration, N.A.R.; Resources, U.G.; Validation, M.U.A.; Writing-original draft, M.S.A. and N.A.R.; Writing-review \& editing, A.Z., M.U.A., and Y.S.R. All authors have read and agreed to the published version of the manuscript.

Funding: The authors thank the technical assistance of UM Power Energy Dedicated Advanced Centre (UMPEDAC), the Higher Institution Centre of Excellence (HICoE) Program Research Grant, UMPEDAC-2018 (MOHE HICOE-UMPEDAC), Ministry of Education Malaysia, TOP100UMPEDAC, 
RU005-2015, University of Malaya and the National Research Foundation of Korea (NRF) grant funded by the Korea government (MSIT) (No. 2020R1A2C1013693).

Institutional Review Board Statement: Not applicable.

Informed Consent Statement: Not applicable.

Data Availability Statement: The prepared samples to support the findings of this study are available from the corresponding authors upon reasonable request.

Conflicts of Interest: The authors declare no conflict of interest.

\section{Appendix A}

Table A1. Indoor testing results.

\begin{tabular}{|c|c|c|c|c|c|c|c|c|}
\hline $\begin{array}{c}\text { Irradiation } \\
\text { Value }\end{array}$ & $\begin{array}{c}\text { Zinc } \\
\text { Concentration }\end{array}$ & Sample 1 & Sample 2 & Sample 3 & Sample 4 & Sample 5 & Mean & $\begin{array}{c}\text { Standard } \\
\text { Deviation }(\%)\end{array}$ \\
\hline \multirow{10}{*}{$200 \mathrm{~W} / \mathrm{m}^{2}$} & $0.5 \%$ & 53.41 & 53.373 & 53.395 & 53.436 & 53.386 & 53.4 & 2.166102 \\
\hline & $1 \%$ & 53.28 & 53.243 & 53.255 & 53.286 & 53.236 & 53.26 & 1.982927 \\
\hline & $3 \%$ & 54.817 & 54.783 & 54.798 & 54.826 & 54.776 & 54.8 & 1.915202 \\
\hline & $5 \%$ & 54.57 & 54.533 & 54.535 & 54.596 & 54.516 & 54.55 & 2.893441 \\
\hline & $7 \%$ & 54.806 & 54.807 & 54.805 & 54.846 & 54.786 & 54.81 & 1.960612 \\
\hline & $10 \%$ & 55.962 & 55.923 & 55.935 & 55.964 & 55.916 & 55.94 & 1.974842 \\
\hline & $15 \%$ & 55 & 54.973 & 54.965 & 55.046 & 54.966 & 54.99 & 3.074411 \\
\hline & $20 \%$ & 54.834 & 54.819 & 54.825 & 54.866 & 54.806 & 54.83 & 2.016928 \\
\hline & $0 \%$ & 45.953 & 45.94 & 45.945 & 45.986 & 45.926 & 45.95 & 2.002998 \\
\hline & - & 34.35 & 34.273 & 34.285 & 34.296 & 34.246 & 34.29 & 3.431035 \\
\hline \multirow{10}{*}{$600 \mathrm{~W} / \mathrm{m}^{2}$} & $0.5 \%$ & 73.682 & 73.661 & 73.675 & 73.716 & 73.666 & 73.68 & 1.940103 \\
\hline & $1 \%$ & 74.303 & 74.273 & 74.282 & 74.326 & 74.266 & 74.29 & 2.18815 \\
\hline & $3 \%$ & 76.61 & 76.533 & 76.555 & 76.606 & 76.546 & 76.57 & 3.18308 \\
\hline & $5 \%$ & 77.13 & 77.103 & 77.105 & 77.126 & 77.086 & 77.11 & 1.616168 \\
\hline & $7 \%$ & 77.88 & 77.813 & 77.815 & 77.876 & 77.816 & 77.84 & 3.106767 \\
\hline & $10 \%$ & 82.282 & 82.271 & 82.285 & 82.326 & 82.286 & 82.29 & 1.877232 \\
\hline & $15 \%$ & 78.74 & 78.703 & 78.715 & 78.746 & 78.696 & 78.72 & 1.982927 \\
\hline & $20 \%$ & 78.52 & 78.493 & 78.505 & 78.546 & 78.486 & 78.51 & 2.138224 \\
\hline & $0 \%$ & 63.848 & 63.801 & 63.815 & 63.856 & 63.78 & 63.82 & 2.851666 \\
\hline & - & 41.94 & 41.913 & 41.925 & 41.966 & 41.906 & 41.93 & 2.138224 \\
\hline \multirow{10}{*}{$800 \mathrm{~W} / \mathrm{m}^{2}$} & $0.5 \%$ & 78.965 & 78.943 & 78.95 & 78.996 & 78.946 & 78.96 & 1.952434 \\
\hline & $1 \%$ & 81.915 & 81.883 & 81.89 & 81.936 & 81.876 & 81.9 & 2.229798 \\
\hline & $3 \%$ & 87.908 & 87.893 & 87.905 & 87.946 & 87.898 & 87.91 & 1.8751 \\
\hline & $5 \%$ & 89.71 & 89.663 & 89.675 & 89.696 & 89.656 & 89.68 & 2.022869 \\
\hline & $7 \%$ & 90.861 & 90.833 & 90.842 & 90.886 & 90.828 & 90.85 & 2.123205 \\
\hline & $10 \%$ & 94.96 & 94.923 & 94.925 & 94.976 & 94.916 & 94.94 & 2.360508 \\
\hline & $15 \%$ & 93.755 & 93.703 & 93.695 & 93.762 & 93.685 & 93.72 & 3.202499 \\
\hline & $20 \%$ & 91.626 & 91.647 & 91.645 & 91.706 & 91.626 & 91.65 & 2.940068 \\
\hline & $0 \%$ & 72.866 & 72.843 & 72.855 & 72.89 & 72.846 & 72.86 & 1.700588 \\
\hline & - & 44.965 & 44.933 & 44.94 & 44.986 & 44.926 & 44.95 & - \\
\hline \multirow{10}{*}{$1000 \mathrm{~W} / \mathrm{m}^{2}$} & $0.5 \%$ & 88.1 & 88.033 & 88.045 & 88.096 & 88.026 & 88.06 & 3.164174 \\
\hline & $1 \%$ & 90.15 & 90.123 & 90.135 & 90.176 & 90.116 & 90.14 & 2.138224 \\
\hline & $3 \%$ & 96.04 & 95.993 & 95.985 & 96.056 & 95.976 & 96.01 & 3.189357 \\
\hline & $5 \%$ & 97.02 & 97.003 & 97.015 & 97.056 & 97.006 & 97.02 & 1.900526 \\
\hline & $7 \%$ & 98.34 & 98.303 & 98.305 & 98.356 & 98.296 & 98.32 & 2.360508 \\
\hline & $10 \%$ & 103.566 & 103.553 & 103.552 & 103.596 & 103.533 & 103.56 & 2.085186 \\
\hline & $15 \%$ & 97.127 & 97.053 & 97.078 & 97.126 & 97.066 & 97.09 & 3.083504 \\
\hline & $20 \%$ & 97.66 & 97.633 & 97.645 & 97.686 & 97.626 & 97.65 & 2.138224 \\
\hline & $0 \%$ & 83.807 & 83.783 & 83.795 & 83.836 & 83.779 & 83.8 & 2.04939 \\
\hline & - & 65.058 & 65.033 & 65.033 & 65.06 & 65.016 & 65.04 & 1.672124 \\
\hline
\end{tabular}




\section{References}

1. Biswas, A.K.; Tortajada, C. Water crisis and water wars: Myths and realities. Int. J. Water Resour. Dev. 2019, 35, 727-731. [CrossRef]

2. Jiang, S.; Li, Y.; Ladewig, B.P. A review of reverse osmosis membrane fouling and control strategies. Sci. Total Environ. 2017, 595, 567-583. [CrossRef] [PubMed]

3. Khairkar, S.R.; Pansare, A.V.; Shedge, A.A.; Chhatre, S.Y.; Suresh, A.; Chakrabarti, S.; Patil, V.R.; Nagarkar, A.A. Hydrophobic interpenetrating polyamide-PDMS membranes for desalination, pesticides removal and enhanced chlorine tolerance. Chemosphere 2020, 258, 127179. [CrossRef] [PubMed]

4. Awad, A.M.; Jalab, R.; Minier-Matar, J.; Adham, S.; Nasser, M.S.; Judd, S. The status of forward osmosis technology implementation. Desalination 2019, 461, 10-21. [CrossRef]

5. Campione, A.; Gurreri, L.; Ciofalo, M.; Micale, G.; Tamburini, A.; Cipollina, A. Electrodialysis for water desalination: A critical assessment of recent developments on process fundamentals, models and applications. Desalination 2018, 434, 121-160. [CrossRef]

6. Tian, H.; Wang, Y.; Pei, Y.; Crittenden, J.C. Unique applications and improvements of reverse electrodialysis: A review and outlook. Appl. Energy 2020, 262, 114482. [CrossRef]

7. Baltes, L.; Patachia, S.; Ekincioglu, O.; Ozkul, H.; Croitoru, C.; Munteanu, C.; Istrate, B.; Tierean, M. Polymer-Cement Composites Glazing by Concentrated Solar Energy. Coatings 2021, 11, 350. [CrossRef]

8. Liu, S.; Wang, Z.; Han, M.; Wang, G.; Hayat, T.; Chen, G. Energy-water nexus in seawater desalination project: A typical water production system in China. J. Clean. Prod. 2020, 279, 123412. [CrossRef]

9. Li, X.; Wang, Z.; Yang, M.; Yuan, G. Dynamic Simulation of a Novel Solar Polygeneration System for Heat, Power and Fresh Water Production based on Solar Thermal Power Tower Plant. J. Therm. Sci. 2020, 29, 378-392. [CrossRef]

10. Liu, F.; Wang, L.; Bradley, R.; Zhao, B.; Wu, W. Highly efficient solar seawater desalination with environmentally friendly hierarchical porous carbons derived from halogen-containing polymers. RSC Adv. 2019, 9, 29414-29423. [CrossRef]

11. Abujazar, M.S.S.; Fatihah, S.; Kabeel, A. Seawater desalination using inclined stepped solar still with copper trays in a wet tropical climate. Desalination 2017, 423, 141-148. [CrossRef]

12. Kabeel, A.; Sathyamurthy, R.; Sharshir, S.W.; Muthumanokar, A.; Panchal, H.; Prakash, N.; Prasad, C.; Nandakumar, S.; El Kady, M. Effect of water depth on a novel absorber plate of pyramid solar still coated with $\mathrm{TiO}_{2}$ nano black paint. J. Clean. Prod. 2019, 213, 185-191. [CrossRef]

13. Saleh, S.M.; Soliman, A.M.; Sharaf, M.A.; Kale, V.; Gadgil, B. Influence of solvent in the synthesis of nano-structured ZnO by hydrothermal method and their application in solar-still. J. Environ. Chem. Eng. 2017, 5, 1219-1226. [CrossRef]

14. El Jirie, N.B.; Capareda, S.C.; Liu, S.; Akbulut, M. Advanced Solar Still Development: Improving Distilled Water Recovery and Purity via Graphene-Enhanced Surface Modifiers. Front. Environ. Sci. 2020, 8, 531049.

15. Imae, I. Reduction of Graphene Oxide Using an Environmentally Friendly Method and Its Application to Energy-Related Materials. Coatings 2021, 11, 297. [CrossRef]

16. Thakur, A.K.; Sathyamurthy, R.; Sharshir, S.W.; Kabeel, A.E.; Elkadeem, M.; Ma, Z.; Manokar, A.M.; Arıc1, M.; Pandey, A.; Saidur, R. Performance analysis of a modified solar still using reduced graphene oxide coated absorber plate with activated carbon pellet. Sustain. Energy Technol. Assess. 2021, 45, 101046.

17. Balachandran, G.B.; David, P.W.; Mariappan, R.K.; Athikesavan, M.M.; Sathyamurthy, R. Improvising the efficiency of singlesloped solar still using thermally conductive nano-ferric oxide. Environ. Sci. Pollut. Res. 2019, 27, 32191-32204. [CrossRef] [PubMed]

18. Kabeel, A.; Omara, Z.; Essa, F.; Abdullah, A.; Arunkumar, T.; Sathyamurthy, R. Augmentation of a solar still distillate yield via absorber plate coated with black nanoparticles. Alex. Eng. J. 2017, 56, 433-438. [CrossRef]

19. Sathyamurthy, R.; Balasubramanian, M.; Devarajan, M.; Sharshir, S.W.; Manokar, A.M. Experimental study on enhancing the yield from stepped solar still coated using fumed silica nanoparticle in black paint. Mater. Lett. 2020, 272, 127873. [CrossRef]

20. Tenthani, C.; Madhlopa, A.; Kimambo, C. Improved solar still for water purification. J. Sustain. Energy Environ. $2012,3,111-113$.

21. Sivakumar, S.; Velmurugan, C.; Dhas, D.E.J.; Solomon, A.B.; Wins, K.L.D. Effect of nano cupric oxide coating on the forced convection performance of a mixed-mode flat plate solar dryer. Renew. Energy 2020, 155, 1165-1172. [CrossRef]

22. Modi, K.V.; Jani, H.K.; Gamit, I.D. Impact of orientation and water depth on productivity of single-basin dual-slope solar still with $\mathrm{Al}_{2} \mathrm{O}_{3}$ and $\mathrm{CuO}$ nanoparticles. J. Therm. Anal. Calorim. 2020, 143, 899-913. [CrossRef]

23. Arunkumar, T.; Murugesan, D.; Raj, K.; Denkenberger, D.; Viswanathan, C.; Rufuss, D.D.W.; Velraj, R. Effect of nano-coated CuO absorbers with PVA sponges in solar water desalting system. Appl. Therm. Eng. 2019, 148, 1416-1424. [CrossRef]

24. Cuce, E.; Cuce, P.M.; Guclu, T.; Besir, A.B. On the use of nanofluids in solar energy applications. J. Therm. Sci. 2020, 29, 513-534. [CrossRef]

25. Kabeel, A.; Omara, Z.; Essa, F. Improving the performance of solar still by using nanofluids and providing vacuum. Energy Convers. Manag. 2014, 86, 268-274. [CrossRef]

26. Fayaz, H.; Rahim, N.; Hasanuzzaman, M.; Nasrin, R.; Rivai, A. Numerical and experimental investigation of the effect of operating conditions on performance of PVT and PVT-PCM. Renew. Energy 2019, 143, 827-841. [CrossRef]

27. Meteoblue. Weather Archive Kuala Lumpur. Available online: https://www.meteoblue.com/en/weather/historyclimate/ weatherarchive/kuala-lumpur_malaysia_1735161?fcstlength=1y\&year=2020\&month=12 (accessed on 22 December 2020).

28. Tang, K.H.D. Climate change in Malaysia: Trends, contributors, impacts, mitigation and adaptations. Sci. Total Environ. 2019, 650, 1858-1871. [CrossRef] 